\title{
A perspective on current research investigating the effects of hormonal contraceptives on determinants of female athlete performance
}

CDD. 20.ed. 613.9432

796.022

796.027

http://dx.doi.org/10.1590/1807-55092016000401087
Daniel MARTIN
Kirsty ELLIOTT-SALE*
*School of Science and Technology, Nottingham Trent University, Nottingham, Nottinghamshire, United Kingdom of Great Britain and Northern Ireland.

Hormonal contraceptives are used by approximately half of female athletes and may affect athletic performance as a result of their action on the endogenous hormonal milieu. In athletes, hormonal contraceptive use appears to have little effect on body composition, however further studies are needed assessing progestin-only contraceptives as they may have a negative effect in the general population. The type of progestin contained within the contraceptive may influence the anabolic response of muscle to loading although this relationship is complex as it may be due to either direct or indirect effects of exogenous hormones on protein synthesis and satellite cell proliferation. The altered hormonal milieu in hormonal contraceptive users has predominately been shown to have no effect on muscle strength and whilst maximal oxygen uptake is sometimes reduced, this does not translate into measures of performance. The majority of previous research has used cross-sectional designs and/or grouped together different types and brands of hormonal contraceptives and little research has been conducted on progestin-only contraceptives in athletes. Future research should use prospective, randomised-controlled designs to assess the effects of all types of hormonal contraceptives on athletic performance in females.

KEY WoRDS: Oestrogen; Progestin; Exercise; Body composition; Oral contraceptive.

\section{Introduction}

The possible interaction between exogenous reproductive hormones and athletic performance in females is an important issue that has been the topic of debate for at least four decades ${ }^{1}$. There are numerous review articles on the effect of oral contraceptives (OC) on athletic performance $e^{2-6}$, however we feel that these reviews are insufficient as they do not include all categories of hormonal contraceptives. In addition to OCs, there are many other delivery systems for hormonal contraceptives including Intrauterine Devices (IUDs), injections, transdermal patches, implants and vaginal rings. TABLE 1 shows the characteristics of each type of hormonal contraceptive.

Most hormonal contraceptives contain the synthetic oestrogen Ethinyl Estradiol (EE), however there are four generations of progestins, each with varying androgenicity and potency; for a comprehensive review see Benagiano et al. ${ }^{7}$. Each type of hormonal contraceptive has multiple formulations and brands that supply oestrogens and/or progestins in various concentrations for different durations ${ }^{8}$. As such, the term "hormonal contraceptives" is an umbrella phrase that refers to any type of exogenous hormones that alters endogenous endocrine function and prevents pregnancy $^{8}$. This is the first paper to consider the effects of a large variety of hormonal contraceptives on athletic performance, as opposed to focussing on OCs as previous reviews have.

Recent data suggest that $-22 \%$ of the general population uses OCs, with $-9 \%$ using other forms of hormonal contraceptives'. In athletes, the prevalence of OC use is estimated to be $40-50 \%{ }^{10-11}$, however the most recent large-scale data was published in 2005 and the use of other methods of hormonal contraceptives, beyond OCs, has not been reported. 
Since this time, the use of long-acting contraceptive methods, such as the IUD and implant, has been increasing ${ }^{12}$ and therefore we suggest that it is important to understand not only how OCs influence performance, but also how other methods of hormonal contraceptives may affect female athletes. This article will present a brief overview of the effects of different types of hormonal contraceptives on a number of factors that influence athletic performance.

TABLE 1 - Characteristics of different types of hormonal contraceptives.

\begin{tabular}{|c|c|c|c|}
\hline Type & Delivery & Frequency & Example of brand \\
\hline Contraceptive patch & $\begin{array}{l}\text { Thin plastic patch that } \\
\text { sticks to the skin \& releases } \\
\text { oestrogen \& progestin } \\
\text { through the skin into } \\
\text { the bloodstream. }\end{array}$ & $\begin{array}{l}\text { New patch once a week for } 3 \\
\text { weeks, no patch on } 4 \text { th week. }\end{array}$ & Evra $^{\circledast}$ \\
\hline Injectable birth control & Injection of a progestin. & Once every 3 months. & $\begin{array}{l}\text { Depo-Provera }^{\circledast} \\
\text { Noristera }^{\circledast}\end{array}$ \\
\hline Implantable rods & $\begin{array}{l}\text { Matchstick-sized, flexible, } \\
\& \text { plastic rod that is inserted } \\
\text { under the skin and releases } \\
\text { a progestin. }\end{array}$ & 5 years. & $\begin{array}{l}\text { Norplant }^{\oplus} \\
\text { Implanon }^{\circledast} \\
\text { Nexplanon }^{\circledast}\end{array}$ \\
\hline Intrauterine devices & $\begin{array}{l}\text { Small, T-shaped device, } \\
\text { inserted into the vagina, } \\
\text { that releases a progestin. }\end{array}$ & 5 years. & $\begin{array}{l}\text { Mirena }^{\oplus} \\
\text { Skyla }^{\circledR}\end{array}$ \\
\hline Oral contraceptives & Consumed in pill form. & $\begin{array}{l}\text { Combined OCs are typically } \\
\text { ingested for } 21 \text { days, followed } \\
\text { by } 7 \text { non-pill taking days. } \\
\text { Progestin-only pills are usually } \\
\text { consumed every day. }\end{array}$ & $\begin{array}{l}\text { Microgynon }^{\oplus} \\
\text { Yasmin }^{\oplus} \\
\text { Marvalon }^{\circledast} \\
\text { Cilest }^{\oplus} \\
\text { Cerazette }^{\oplus}\end{array}$ \\
\hline Vaginal rings & $\begin{array}{l}\text { Flexible plastic ring inserted } \\
\text { into the vagina that releases } \\
\text { oestrogen and progestin. }\end{array}$ & $\begin{array}{l}\text { Worn for } 21 \text { days, removed } \\
\text { for } 7 .\end{array}$ & NuvaRing ${ }^{\circledR}$ \\
\hline
\end{tabular}

\section{Do hormonal contraceptives affect body composition?}

Body composition is an important determinant of athletic performance; excess fat mass can impair performance by negatively affecting the powerto-weight ratio $^{13}$, reducing speed and agility ${ }^{14}$, limiting the availability of lean mass in weight category sports ${ }^{13}$ and hindering aesthetic sports ${ }^{15}$. Hormonal contraceptives are widely purported to induce weight gain by athletes ${ }^{16}$ and the general population ${ }^{17}$ although systematic reviews of combined contraceptives ${ }^{18}$ and progestinonly contraceptives ${ }^{17}$ have reported inconsistent findings. In the general population, several studies have shown that the Depot Medroxyprogesterone Acetate (DMPA) injection increases fat mass when compared to combined OC use $\mathrm{O}^{19-20}$ and nonhormone controls ${ }^{19,21}$. Levonorgestrel IUD use resulted in a $2.5 \%$ increase in fat mass after 12 months usage, compared to a non-hormonal copper based (TCu380A) IUD group who lost $1.3 \%$ fat mass ${ }^{22}$ and Levonorgestrel implant (Norplant) use resulted in significant increases in body mass when compared to non-hormone groups after $6^{23}$ and 12 months ${ }^{24}$. The use of an etonogestrel implant (Implanon) has also resulted in body mass increases of 3\% over 2 years $^{25}$. This evidence suggests that progestin-only contraceptives may result in greater increases in body mass than combined contraceptives in the general population, although these data may not be applicable to athletes as they exercise frequently and monitor their dietary energy intake closely ${ }^{15}$.

In a prospective randomised-controlled study, Proctor-Gray et al. ${ }^{16}$ demonstrated that athletes 
who were given a combined OC (Norgestrel; $\mathrm{n}=$ 69) lost more body and fat mass and gained more lean mass than a control group $(\mathrm{n}=81)$ not using hormonal contraception. Conversely, RickenLund et al. ${ }^{26}$ found that 10 months OC (Levonorgestrel) use increased body mass $(4.3 \%)$ and fat mass $(17.3 \%)$ in oligomenorrheic participants $(n=$ 13) but did not significantly affect eumenorrheic participants body composition $(\mathrm{n}=13)$, despite mean increases of $3.0 \%$ and $3.8 \%$ for body and fat mass. RicKenlund et al. ${ }^{26}$ used a relatively small sample size and in the absence of a power calculation it may be that the sample size was not sufficient to detect significant changes in body composition. This highlights the need for further research before the relationship between hormonal contraceptive use and body composition is fully understood in athletes.

Although data are inconclusive for contraceptive use and weight-gain, mechanisms have been identified which support a role for both combined and progestin-only contraceptives increasing body mass. Synthetic progestins have been hypothesised to act in a glucocorticoid-like manner, which results in increased appetite and visceral fat deposition ${ }^{27-30}$. Androgenic contraceptives may also interfere with appetite regulation by suppressing the secretion of the satiating hormone cholecystokinin ${ }^{25}$. It is unclear whether the addition of oestrogens in combined contraceptives influences the effects of the progestins ${ }^{26}$. However, in both combined and progestin-only contraceptives there is a down-regulation of reproductive hormones which has been demonstrated to reduce basal metabolic rate ${ }^{27-28}$, increase visceral fat deposition ${ }^{29}$, increase concentrations of appetite-stimulating hormones ${ }^{30}$ and reduce the concentrations of satiating hormones ${ }^{30}$. The combination of these factors suggests that contraceptive use may result in weight gain but this has not been demonstrated in athletes ${ }^{16,24}$

\section{Is there a relationship between hormonal contraceptives and muscle mass?}

The ability to accrue muscle mass in response to training is beneficial as lean body mass is related to performance indices such as strength, speed and endurance ${ }^{31-32}$. The regulation of muscle anabolism and catabolism is affected by many factors and exogenous oestrogens and progestins may directly influence this process or indirectly influence hypertrophic adaptations by altering the concentrations of anabolic hormones ${ }^{33}$. In the general population, progestin only-contraceptives appear to have a negative effect on lean mass. Bonny et al. ${ }^{20}$ reported that women who received the DMPA injection lost 3.6\% lean mass over 2 years compared to a DMPA and oestradiol group $(-1.2 \%)$, OC group $(+0.6 \%)$ or control group with no hormones $(+0.6 \%)$. Women using a Levonorgestrel IUD lost $1.4 \%$ of their lean mass after 1 year compared to a $1.0 \%$ increase in lean mass in women using a copper-based (Tcu380A) IUD $^{22}$ and combined OCs have also been observed to have a negative effect on lean mass compared to control populations ${ }^{19}$.

In athletes, Proctor-Gray et al..$^{16}$ demonstrated that regularly menstruating runners assigned to a second generation $\mathrm{OC}(30 \mu \mathrm{g} \mathrm{EE}$ and $0.3 \mathrm{mg}$ Norgestrel) for 2 years accrued a greater amount of lean mass $\left(0.67 \mathrm{~kg} \cdot \mathrm{year}^{-1}\right)$ than a control group of runners given no hormones $\left(-0.10 \mathrm{~kg} \cdot \mathrm{year}^{-1}\right)$. The mechanisms behind these changes were not reported and as no indices of performance were measured it is unclear whether these changes resulted in improved performance. To date, only two studies have examined how $\mathrm{OC}$ use influences the response to resistance training ${ }^{34-35}$. Nichols et al. ${ }^{34}$ assessed the response of athletes using various preparations of OCs $(\mathrm{n}=13)$ and athletes not using hormonal contraception $(n=18)$ to 12 weeks of resistance training. Strength was improved in both groups, with no apparent differences between groups, although this study did not control for menstrual cycle phase when measuring strength in the control group, which has been shown to affect force production ${ }^{36}$. In contrast, LeE et al. ${ }^{35}$ found that non-OC users (n $=39)$ gained significantly more muscle mass $(+3.5 \%)$ than OC users $(\mathrm{n}=34 ;+2.1 \%)$ following a 10 week training programme. Further differences were observed within the OC group, with those taking low androgenicity OCs having a $2.5 \%$ increase compared to a $0.3 \%$ increase in high androgenicity OC users. It is likely that the differences in muscle mass shown by LeE et al. ${ }^{35}$ of sufficient magnitude to effect overall athletic performance. The higher 
androgenicity progestins may have a higher affinity to androgen receptors, which limits the binding of testosterone and thus supresses muscle strength gain $^{37}$. These findings suggests that exogenous hormones may influence the anabolic response of muscle to resistance exercise.

The myofibrillar protein fractional synthetic rate (FSR) does not vary across the menstrual cycle ${ }^{38}$, however Hansen et al. ${ }^{39}$ demonstrated that females using a third generation OC $(30 \mu \mathrm{g}$ EE and 0.0075 $\mathrm{g}$ Gestogen) had a lower FSR than second generation users $(35 \mu \mathrm{g}$ EE and $0.25 \mathrm{mg}$ Norgestimate) and no hormone controls. This suggests that the exogenous synthetic component of contraceptives can affect protein synthesis, unlike endogenous female reproductive hormones. Recent evidence suggests that oestrogen receptors (ER $\alpha$ and $E R \beta)$ within the muscle can stimulate the proliferation of satellite cells via the PI3K/Akt pathway for muscle growth and repair ${ }^{33,40}$. EE increases the proliferation of satellite cells in rat muscle tissue ${ }^{41}$, indicating that the synthetic component of hormonal contraceptives may have a direct anabolic effect on muscle, possibly due to a local activation of IGF-1 pathway through an autocrine or paracrine manner ${ }^{42}$.
Hormonal contraceptives may indirectly influence muscle metabolism by altering the concentrations of anabolic hormones such as testosterone, Growth Hormone $(\mathrm{GH})$ and insulin-like growth factor 1 $(\mathrm{IGF}-1)^{43}$. A recent meta-analysis showed that OC use reduced free testosterone by $61 \%$ compared to non-users ${ }^{44}$, possibly due to an increase in sex hormone binding globulin concentration, which binds to testosterone rendering it inactive. OC use increases $\mathrm{GH}$ concentrations $^{45-46}$ with second $(30 \mu \mathrm{g}$ EE and 0.125 mg Levonorgestrel) and fourth generation $(30 \mu \mathrm{g} \mathrm{EE}$ and $2 \mathrm{mg}$ Dienogest) OCs reducing concentrations of IGF-1, but not affecting IGF binding protein-1 concentrations $s^{45}$. The generation of contraceptive influences the response of IGF-1; 30\% reduction following fourth generation OC use compared to $12 \%$ reduction following second generation use ${ }^{46}$, possibly as the androgenic Levonorgestrel opposes the effects of oestrogen on IGF-1 concentrations. In addition, twelve weeks use of a transdermal oestrogen patch (Estraderm) and oral oestrogen (Estrace) has also been shown to increase $\mathrm{GH}$ release ${ }^{47}$. It is currently unclear if these differences in anabolic hormone concentrations with different methods of contraception influence the response to strength training in female athletes.

\section{How do hormonal contraceptives influence muscle strength?}

A cross-sectional study found poorer handgrip force production and endurance in OC users (8 different types) than eumenorrheic controls ${ }^{48}$. However, studies comparing pill-taking days and non-pill taking days have generally found no difference in strength at these time points ${ }^{49-52}$, although there is some limited evidence that strength is greater on non-pill taking days $^{53}$. LEBRUN ${ }^{5}$, using a prospective research design, reported no difference in knee flexion and extension strength after 2 months of first generation OC use. To date, no research has been conducted assessing muscle strength in progestin-only OCs or other methods of hormonal contraception and few studies have been conducted in athletic populations ${ }^{5,53}$.
The reduction in free testosterone and oestrogen concentration with contraceptive use ${ }^{18,44}$ may affect muscle force production as both hormones have a non-genomic action on skeletal muscle, by increasing intracellular calcium concentrations and influencing the contractile properties of the muscle ${ }^{54-55}$. Despite this, few studies have shown an effect of down-regulated reproductive hormones on skeletal muscle force production ${ }^{56}$. Indeed, previous research from our group ${ }^{57}$ demonstrated that supra-physiological concentrations of oestrogen and progesterone do not influence force production in non-trained women. 


\section{Is oxygen uptake affected by hormonal contraceptive use?}

Many studies have shown that OC use results in a significant reduction in maximal oxygen uptake $\left(\mathrm{VO}_{2 \max }\right)$ in non-athletic women after 2-6 months use ${ }^{53,58-62}$ which is reversed when OC use is terminated ${ }^{58,60}$. This may be due to a reduced activation of the sympathetic nervous system in ovarian suppressed women ${ }^{63}$ or a reduction in mitochondrial citrate ${ }^{58}$. However, other more recent studies have found no effect of OC use on $\mathrm{VO}_{2 \max }$ in athletes ${ }^{64-65}$, possibly due to the use of different formulations of OC or the training status of the participants.

\section{What are the effects of hormonal contraceptives on performance tests?}

BRYNER et al. ${ }^{60}$ detected a $7 \%$ reduction in $\mathrm{VO}_{2 \max }$ with OC use (35 $\mu \mathrm{g}$ EE, $1 \mathrm{mg}$ Norethindrone), although this had no effect on performance in a treadmill running exercise capacity test. Similarly, JoYCE et al. ${ }^{62}$ observed a reduced $\mathrm{VO}_{2 \max }$ in OC users compared to eumenorrheic controls; however there was no difference in cycling capacity performance. In addition, no differences were observed in rowing exercise capacity ${ }^{65}$ or $200 \mathrm{~m}$ swim performance ${ }^{66}$ at different stages of the OC cycle in well-trained athletes. In a prospective study, RickenLund et al. ${ }^{26}$ measured endurance capacity, isometric quadriceps strength and handgrip strength in 26 female endurance athletes (13 eumenorrheic and 13 oligo-amenorrheic) before and after 10 months treatment with an OC (30 $\mu \mathrm{g}$ EE and $150 \mu \mathrm{g}$ Levonorgestrel). There was no effect of OC consumption, except a small decrease in exercise capacity in the initially oligo-amenorrheic group, although this may have been due to the inferior response to training observed in ovarian/energy suppressed athletes ${ }^{67}$. Further studies using exercise performance tests are needed, as the majority of past research has examined exercise capacity tests, which are not as ecologically valid as performance tests.

\section{Final considerations}

As we have demonstrated in this paper, it is difficult to determine the role of hormonal contraceptives on performance as the majority of studies are cross-sectional and there is a paucity of prospective, randomised-controlled trials. This is especially true for studies using progestin-only contraceptives, which have barely been considered in the general population and have not been studied at all in an athletic population (TABLE 2). A large number of studies have compared pill-taking days to non-pill taking days, even though data from our laboratory has shown there is no significant difference in hormone profile between these conditions ${ }^{68}$. Moreover, different pill types and formulations are often grouped together making it difficult to discern possible effects, as the potency and androgenicity of the synthetic hormones may influence the response ${ }^{7}$ and we have previously demonstrated that the hormonal profile is affected by the brand of hormonal contraceptive ${ }^{68}$.

It appears that the effects of hormonal contraceptives observed in the general population are not apparent in athletes, however further research is required to assess this. In the case of body composition, it may be that athletes respond differently to hormonal contraceptives, as athletes exercise more frequently and monitor their dietary intake more carefully ${ }^{15}$. In terms of muscle mass, the increased habitual exercise level and loading in athletes may provide a greater stimulus for muscle anabolism, which may differentiate the two populations. There may be complex interactions between direct and indirect effects of hormonal contraceptive on the anabolic response of muscle to resistance exercise, however these effects are currently unclear. The acute effects of hormonal contraceptives are more apparent with the majority of studies observing no effect on muscle strength or performance, despite reductions in $\mathrm{VO}_{2 \max }$. We believe that additional studies on the effects of progestin-only contraceptives on muscle strength and $\mathrm{VO}_{2 \max }$ are needed as this area has not been evaluated and newer formulations of OCs should be incorporated into research. 
It is also useful to note that few studies address the issue of sample size and power, with only a small number of studies with athletic participants reporting priori power analysis ${ }^{52,62,64}$. This issue makes it difficult to conclude either the statistical or clinical significance of many of the studies included in this overview, however it is clear that further research on the effects of hormonal contraceptives is warranted and should not be confined to oral contraceptives only. In particular, we propose that the effects of long-acting, reversible, progestin-only contraceptives should be considered as their prevalence is increasing and these are likely to have different effects on performance than combined contraceptives.

This perspective also highlights the lack of information pertaining to the prevalence of hormonal contraceptive use in athletes. It would be beneficial to know the extent of hormonal contraceptive use in athletes so that future research can be directed appropriately. For example, in the general population the patch and ring are very rarely used: $0.1 \%$ use for patch and no recorded use of vaginal ring in 194,000 participants ${ }^{9}$, therefore if athletes show a similar trend for usage, it may not be justified to recommend research into their effects in an athletic population. However, if athletes show an increased use of the patch or ring than the general population, then the composition of these contraceptives (exposure to ethinyl estradiol with the nuvaring is 3.4 times less than the contraceptive patch and 2.1 times less than OCs. ${ }^{69}$ may indicate the need for more research. Therefore, we strongly recommend that research into the prevalence of hormonal contraceptive use in athletes should be conducted.

TABLE 2 - A summary of the effects of hormonal contraceptives on determinants of athletic performance.

\begin{tabular}{|c|c|c|c|}
\hline \multirow{6}{*}{$\begin{array}{l}\text { Progestin-on Iy } \\
\text { contraceptives have } \\
\text { been grouped together } \\
\text { due to the paucity of } \\
\text { research on these } \\
\text { contraceptive delivery } \\
\text { systems in athletes. }\end{array}$} & $\begin{array}{l}\text { Determinants of } \\
\text { athletic performance }\end{array}$ & Combined oral contraceptives & Progestin-only contraceptives \\
\hline & Body composition & $\begin{array}{l}\text { Conflicting data showing combined } \\
\text { oral contraceptive use both increased } \\
\text { and reduced body mass and fat mass in } \\
\text { athletes }{ }^{16,26} \text {. }\end{array}$ & $\begin{array}{l}\text { Several reports of negatives effects in the } \\
\text { general population although no studies } \\
\text { have been conducted in athletes }{ }^{19-25} \text {. }\end{array}$ \\
\hline & Muscle mass accretion & $\begin{array}{l}\text { Combined oral contraceptive use may } \\
\text { have a positive or negative effect on } \\
\text { strength gains depending upon the } \\
\text { progestin used }^{16,19-20,34-35} \text {. }\end{array}$ & $\begin{array}{l}\text { Insufficient evidence, although the type } \\
\text { of progestin-used may influence the } \\
\text { anabolic response of muscle to resistance } \\
\text { exercise }^{20,22} \text {. }\end{array}$ \\
\hline & Muscle strength & $\begin{array}{l}\text { The majority of studies have reported } \\
\text { no acute effects of combined oral } \\
\text { contraceptives on muscle strength }{ }^{49-52} \text {. }\end{array}$ & $\begin{array}{l}\text { Insufficient evidence to draw a } \\
\text { conclusion. }\end{array}$ \\
\hline & Oxygen uptake & $\begin{array}{l}\text { Combined oral contraceptive use may } \\
\text { reduce } \mathrm{VO}_{2 \max } \text { although this is less } \\
\text { apparent in trained athletes } \\
\text { a-65. }\end{array}$ & $\begin{array}{l}\text { Insufficient evidence to draw a } \\
\text { conclusion. }\end{array}$ \\
\hline & Performance tests & $\begin{array}{l}\text { Combined oral contraceptives do not } \\
\text { appear to acutely effect exercise capacity } \\
\text { or performance tests }{ }^{26,60,62,65-66} \text {. }\end{array}$ & $\begin{array}{l}\text { Insufficient evidence to draw a } \\
\text { conclusion. }\end{array}$ \\
\hline
\end{tabular}




\section{Resumo}

Uma perspectiva sobre a investigação dos efeitos dos contraceptivos hormonais sobre os fatores determinantes do desempenho de mulheres atletas

Os métodos contraceptivos hormonais são usados por aproximadamente metade das atletas do sexo feminino e podem afetar o desempenho atlético como resultado de sua ação hormonal sistêmica. Nas atletas, o uso de anticoncepcionais parece ter pouco efeito sobre a composição corporal, porém novos estudos são necessários para avaliar os efeitos dos contraceptivos derivados apenas de progestina, pois podem ter um efeito negativo na população em geral. 0 tipo de progestina contido dentro do contraceptivo pode influenciar a resposta anabólica do músculo, embora esta relação seja complexa em virtude dos efeitos diretos ou indiretos de hormônios exógenos na sintese da proteína e na proliferação das células satélites. A resposta sistêmica hormonal alterada em usuárias de contraceptivos parece não influenciar a força muscular e, embora o consumo máximo de oxigênio às vezes seja reduzida, isso não afeta as medidas de desempenho. A maioria das pesquisas utilizou desenhos transversais e/ou agrupou diferentes tipos e marcas de anticoncepcionais hormonais e poucos estudos têm sido realizada sobre anticoncepcionais com progestina em atletas. Futuros estudos devem usar desenhos experimentais prospectivos, randomizados e controlados para avaliar os efeitos de todos os tipos de contraceptivos hormonais no desempenho atlético em mulheres.

Palavras-chave: Estrogênio; Progestina; Exercício; Composição corporal; Contraceptivo oral.

\section{References}

1. McNeill AW, Nozingo E. Changes in the metabolic cost of standardized work associated with the use of an oral contraceptive. J Sports Med Phys Fit. 1981;21:238-4.

2. Rechichi C, Dawson B, Goodman C. Athletic performance and the oral contraceptive. Int J Sports Physiol Perf. 2009;4:151-62.

3. Burrows M, Peters CE. The influence of oral contraceptives on athletic performance in female athletes. Sports Med. 2007;37:557-74.

4. Bennell K, White S, Crossley K. The oral contraceptive pill: a revolution for sports women? Br J Sports Med. 1999;33:231-8.

5. Lebrun CM. Effect of different phases of the menstrual cycle and oral contraceptives on athletic performance. Sports Med. 1993;16:400-10.

6. Lebrun CM. The effect of the phase of the menstrual cycle and the birth control pill on athletic performance. Clin Sports Med. 1994;13:419-41.

7. Benagiano G. Primiero FM, Farris M. Clinical profile of contraceptive progestins. Eur J Contracep Reprod Health Care. 2004;3:182-93.

8. Rivera R, Yacobson I, Grimes D. The mechanism of action of hormonal contraceptives and intrauterine contraceptive devices. Am J Obstet Gynecol. 1999;5:1263-9.

9. Cea-Soriano L, García Rodríguez LA, Machlitt A, Walllander MA. Use of prescription contraceptive methods in the UK general population: a primary care study. BJOG: Int J Obstet Gynecol. 2014;1:53-61.

10. Brynhildsen J, Lennartsson H, Klemetz M, Dahlquist P, Hedin B, Hammar M. Oral contraceptive use among female elite athletes and age-matched controls and its relation to low back pain. Acta Obstet Gynecol Scand. 1997;9:873-8.

11. Torstveit M, Sundgot-Borgen J. Participation in leanness sports but not training volume is associated with menstrual dysfunction: a national survey of 1276 elite athletes and controls. Br J Sports Med. 2005;3:141-7.

12. Finer LB, Jerman J, Kavanaugh ML. Changes in use of long-acting contraceptive methods in the United States, 20072009. Fertil Steril. 2012;4:893-7.

13. Slater GJ, Rice AJ, Mujika I, Hahn AG, Sharpe K, Jenkins DG. Physique traits of lightweight rowers and their relationship to competitive success. 2005;10:736-41.

14. Nikolaidis PT. Body mass index and body fat percentage are associated with decreased physical fitness in adolescent and adult female volleyball players. J Res Med Sci. 2013;1:22-6.

Rev Bras Educ Fís Esporte, (São Paulo) 2016 Out-Dez; 30(4):1087-96 • 1093 
15. Sundgot-Borgen J, Torstveit MK. Prevalence of eating disorders in elite athletes in higher than in the general population. Clin J Sport Med. 2004;14:25-32.

16. Proctor-Gray E, Cobb KL, Crawford SL, et al. Effect of oral contraceptives on weight and body composition in young female runners. Med Sci Sports Exerc. 2008;7:1205-12.

17. Lopez LM, Edelman A, Chen M, Otterness C, Trussell J, Helmerhorst FM. Progestin-only contraceptives: effects on weight. Cochrane Database Syst Rev. 2013;7:1-40.

18. Gallo MF, Lopez LM, Grimes DA, Carayon F, Schulz KF, Helmerhorst FM. Combination contraceptives: effects on weight. Cochrane Database Syst Rev. 2014;1:1-73.

19. Berenson AB, Rahman M. Changes in weight, total fat, percent body fat, and central-to-peripheral fat ratio associated with injectable and oral contraceptive use. Am J Obstet Gynecol. 2009;200:29e1-329e8.

20. Bonny AE, Secic M, Cromer BA. A longitudinal comparison of body composition changes in adolescent girls receiving hormonal contraception. J Adolesc Health. 2009;4:423-5.

21. Pantoja M, Medeiros T, Baccarin MC, Morais S, Fernandes AM. Variation of weight among users of the contraceptive with depot medroxyprogesterone acetate according to body mass index in a six-year follow-up. Rev Bras Ginecol Obstet. 2009;8:380-4.

22. Dal'Ava, N, Bahamondes L, Bahamondes V, de Olivera Santos A, Monteiro I. Body weight and composition in users of levonorgestrel-releasing intrauterine system. Contraception. 2012;86:250-5.

23. Salem HT, Abdullah KA, Shaaban MM. Norplant and lactation. Assuit, Egypt, Assuit University, 1984;139-49.

24. Sule S, Shittu O. Weight changes in clients on hormonal contraceptives in Zaria, Nigeria. Afr J Reprod Health. 2005;2:92-100.

25. Beertuuizen R, van Beek A, Massai R, Mäkäräinen L, in’t Hout J, Coelingh Bennink H. Bone mineral density during long-term use of the progestogen contraceptive implant Implanon compared to a non-hormonal method of contraception. Hum Reprod. 2000;15:118-22.

26. Rickenlund A, Carlström K, Ekblom B, Brismar TB, Von Schoultz B, Hirschberg AL. Effects of oral contraceptives on body composition and physical performance in female athletes. J Clin Endocrinol Metab. 2004;9:4364-70.

27. Ishida Y, Ishida Y, Heersche JN. Pharmacologic doses of medroxyprogesterone may cause bone loss through glucocorticoid activity: an hypothesis. Osteoporosis Int. 2002;8:601-5.

28. Galitzky J, Bouloumié A. Human visceral-fat-specific glucocorticoid tuning of adipogenesis. Cell Metab. 2013;1:3-5.

29. Berthon BS, MacDonald-Wicks LK, Wood LG. A systematic review of the effect of oral glucocorticoids on energy intake, appetite, and body weight in humans. Nutr Res. 2014;3:179-90.

30. Govender Y, Avenant C, Verhoog NJ, et al. The injectable-only contraceptive medroxyprogesterone acetate, unlike norethisterone acetate and progesterone, regulates inflammatory genes in endocervical cells via the glucocorticoid receptor. PLoS One. 2014;5:e96497.

31. Cosgrove MJ, Wilson J, Watt D, Grant SF. The relationship between selected physiological variables of rowers and rowing performance as determined by a 2000m ergometer test. J Sports Sci. 1999;11:845-52.

32. Carlsson M, Carlsson T, Hammarström D, Malm C, Tonkonogi M. Lean mass predicts race performance of elite cross-country skiers. Int J Sports Physiol Perform. 2014;Epub.

33. Deil P. The function of the estrogen receptor in skeletal muscle mass and regeneration. Acta Physiol (Oxf). 2014;Epub.

34. Nichols AW, Hetzler RK, Villanueva RJ, Stickley CD, Kimura IF. Effects of combination oral contraceptives on strength development in women athletes. J Strength Cond Res. 2008;5:1625-32.

35. Lee CW, Newman MA, Reichman SE. Oral contraceptive use impairs muscle gains in young women. FASEB J. 2009;23:955.25.

36. Phillips SK, Sanderson AG, Birch K, Bruce SA, Woledge RC. Changes in maximal voluntary force of human adductor pollicis muscle during the menstrual cycle. J Physiol. 1996;2:551-7.

37. Phillips A, Demarest K, Hahn DW, Wong F, McGuire JL. Progestational and androgenic receptor binding affinities and in vivo activities of norgestimate and other progestins. Contraception. 1990;4:399-410.

38. Miller BF, Hansen M, Olesen JL, et al. No effect of menstrual cycle on myofibrillar and connective tissue protein synthesis in contracting skeletal muscle. Am J Physiol Endocrinol Metab. 2006;290:163-8.

39. Hansen M, Langberg H, Holm L, et al. Effect of administration of oral contraceptives on the synthesis and breakdown of myofibrillar proteins in young women. Scand J Med Sci Sports. 2011;21:62-72.

40. Mangan G, Bombardier E, Mitchell AS, Quadrilatero J, Tiidus PM. Oestrogen-dependent satellite cell activation and proliferation following a running exercise occurs via the PI3K signalling pathway and not IGF-1. Acta Physiol (Oxf). 2014; 212:75-85. 
41. Enns DL, Tiidus PM. Estrogen influences satellite cell activation and proliferation following downhill running in rats. J App Physiol. 2008;2:347-53.

42. Pöllänen E, Ronkainen PHA, Horttanainen M, et al. Effect of combined hormone replacement therapy or its effective agents on the IGF-1 pathway in skeletal muscle. Growth Horm IGF Res. 2010;20:372-9.

43. Bhasin S, Storer TW, Berman N, et al. The effects of supraphysiologic doses of testosterone on muscle size and strength in normal men. N Engl J Med. 1996;4;1-7.

44. Zimmerman Y, Eijkemans MJC, Coelingh Bennink HJT, Blankenstein MA, Fauser BCJM. The effect of combined oral contraception on testosterone levels in healthy women: a systematic review and analysis. Hum Reprod Update. 2013;1:1-30.

45. Balogh A, Kauf E, Vollanth R, Gräser G, Klinger G, Oettel M. Effects of two oral contraceptives on plasma levels of insulin-like growth factor 1 (IGF-1) and growth hormone (GH). Contraception. 2000;5:259-69.

46. Rickenlund A, Thoren M, Nybacka A, Frystyk J, Linden Hirschberg A. Effects of oral contraceptives on diurnal profiles of insulin, insulin-like growth factor binding protein-1, growth hormone and cortisol in endurance athletes with menstrual disturbances. Hum Reprod. 2010;1:85-93.

47. Friend KE, Hartman ML, Pezzoli SS, Claset JL, Thorner MO. Both oral and transdermal estrogen increase growth hormone release in postmenopausal women: a clinical research center study. J Clin Endocrinol Metab. 1996;6:2250-6.

48. Wirth JC, Lohman TG. The relationship of static muscle function to use of oral contraceptives. Med Sci Sport Exerc. 1982;1:18-20.

49. Elliott KJ, Cable NT, Reilly T. Does oral contraceptive use affect maximum force production in women? Br J Sports Med. 2005;39:15-9.

50. Peters C, Burrows M. Androgenicity of the progestin in oral contraceptives does not affect maximal leg strength. Contraception. 2006;6:487-491

51. Sarwar E, Beltran Niclos B, Rutherford OM. Changes in muscle strength, relaxation rate and fatigability during the human menstrual cycle. J Physiol. 1996;1:267-72.

52. Enkeros L, Hirschberg AL, Heijne A, Fridén C. Oral contraceptives do not affect muscle strength and hop performance in active women. Clin J Sport Med. 2013,3:202-7.

53. Rechichi C, Dawson B. Effect of oral contraceptive cycle phase on performance in team sport players. J Sci Med Sport. 2009; 12:190-5.

54. Morley P, Whitfield JF, Vanderhyden BC, Tsang BK, Schwartz JL. A new, nongenomic estrogen action: the rapid release of intracellular calcium. Endocrinol. 1992;3:1305-12.

55. Dent JR, Fletcher DK, McGuigan MR. Evidence for a non-genomic action of testosterone in skeletal muscle which may improve athletic performance. J Sports Sci Med. 2012;11:363-70.

56. Elliott KJ, Martin D. Short communication: The use of different models of female reproductive status in human performance research; with a specific focus on muscle strength. Androl Gyneclo: Curr Res. 2013;4.

57. Elliott KJ, Cable NT, Reilly T, Sefton V, Kingsland C, Diver M. Effects of supra-physiological changes in ovarian hormone levels on maximum force production of the first dorsal interosseus muscle. Exp Physiol. 2004;2:215-23.

58. Dagget A, Davies B, Boobis L. Physiological and biomechanical responses to exercise following oral contraceptive use. Med Sci Sport Exerc. 1983;15:174.

59. Notelovitz M, Zauner C, McKenzie L. The effect of low-dose contraceptives on cardiorespiratory function, coagulation, and lipids in exercising young women: a preliminary report. Am J Obstet Gynecol. 1987;156:591-8.

60. Bryner RW, Toffle RC, Ullrich IH, Yeater RA. Effect of low dose oral contraceptives on exercise performance. Br J Sports Med. 1996;1: 36-40.

61. Suh SH, Casazza GA, Horning MA, Miller BF, Brooks GA. Effects of oral contraceptives on glucose flux and substrate oxidation rates during rest and exercise. J Appl Physiol. 1985;1:285-94.

62. Joyce S, Sabapathy S, Bulmer A, Minahan C. Effect of long-term oral contraceptive use on determinants of endurance performance. J Strength Cond Res. 2013;7;1891-6.

63. Schall K, Van Loan MD, Cazazza GA. Reduced catecholamine response to exercise in amenorrheic athletes. Med Sci Sports Exerc. 2011;43:34-43.

64. Rebelo ACS, Zuttin RS, Verlengia R, Cesar MC, Sa MFS, Silva E. Effect of low-dose combined oral contraceptive on aerobic capacity and anaerobic threshold level in active and sedentary young women. Contraception. 2010;1:309-15.

65. Vaiksaar S, Jürimäe J, Mäestu J, et al. Phase of oral contraceptive cycle and endurance capacity of rowers. Percep Mot Skills. 2011;3:764-72. 
Martin D \& Elliott-Sale K.

66. Rechichi C, Dawson B. Oral contraceptive use does not affect $200 \mathrm{~m}$ swim time trial performance. J Strength Cond Res. 2012;4:961-7.

67. VanHeest JL, Rodgers CD, Mahoney CE, De Souza MJ. Ovarian suppression impairs sport performance in junior elite female swimmers. Med Sci Sports Exerc. 2014;1:156-66.

68. Elliott-Sale KJ, Smith S, Bacon J, et al. Examining the role of oral contraceptive users as an experimental and/or control group in athletic performance studies. Contraception. 2013;88:408-12.

69. van den Huevel MW, van Bragt AJ, Alnabawy AK, Kaptein MC. Comparison of ethinylestradiol pharmacokinetics in three hormonal contraceptive formulations: the vaginal ring, the transdermal patch and an oral contraceptive. Contraception. 2005;72:168-74.

ADRESS

Daniel Martin

Sport Science Department, Sport, Health and Performance Enhancement (SHAPE) Research Group School of Science and Technology Nottingham Trent University

Erasmus Darwin Building, Room 259

Nottingham Nottinghamshire NG11 8NS

United Kingdom of Great Britain and Northern Ireland

Submitted: 08/06/2015

Revised: 09/28/2015

Accepted: 10/09/2015 e-mail: daniel.martin@ntu.ac.uk

1096 • Rev Bras Educ Fís Esporte, (São Paulo) 2016 Out-Dez; 30(4):1087-96 